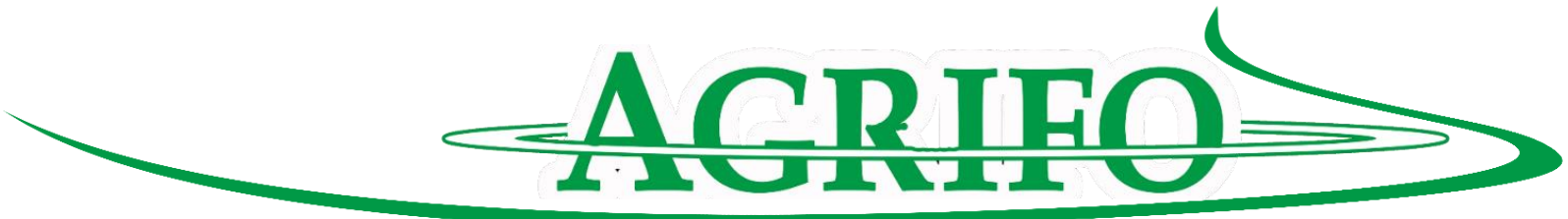

\title{
ANALISIS PENGARUH LUAS LAHAN DAN TENAGA KERJA TERHADAP PRODUKSI KAKAO PERKEBUNAN RAKYAT DI PROVINSI ACEH
}

\author{
Intan Alkamalia ${ }^{1}$, Mawardati², dan Setia Budi
}

email: kamallia91@gmail.com

\section{ABSTRAK}

Perkebunan merupakan salah satu sub sektor pertanian. Indonesia merupakan salah satu produsen kakao tersebar di dunia. Perkebunan kakao di Indonesia sebagian besar dikelola oleh perkebunan rakyat. Perkebunan rakyat tersebut tersebar di berbagai Provinsi salah satunya Provinsi Aceh. Pengembangan perkebunan kakao rakyat di Aceh pada tahun 2006 - 2010 mengalami peningkatan terhadap luas lahan dan jumlah petani kakao tetapi produksi dan produktivitas kakao perkebunan rakyat mengalami fluktuasi. Metode yang digunakan adalah analisis regresi dengan model fungsi produksi Cobb Douglas. Hasil penelitian menunjukkan bahwa secara serempak luas lahan $\left(\mathrm{X}_{1}\right)$ dan tenaga kerja $\left(\mathrm{X}_{2}\right)$ berpengaruh signifikan terhadap produksi kakao $(\mathrm{Y})$ pada nilai probabilitas $0,000<\alpha=0,01$. Sedangkan secara parsial luas lahan $\left(\mathrm{X}_{1}\right)$ berpengaruh signifikan terhadap produksi kakao (Y) pada nilai probabilitas $0,000<\alpha=0,01$ tetapi tenaga kerja $\left(\mathrm{X}_{2}\right)$ tidak berpengaruh signifikan terhadap produksi kakao $(\mathrm{Y})$ pada nilai probabilitas 0,661 $<\alpha=0,05$. Elastisitas produksi kakao di Provinsi Aceh berada pada kondisi increasing return to scale.

Kata Kunci : Luas Lahan, Tenaga Kerja, Produksi, dan Perkebunan Rakyat

\section{PENDAHULUAN}

Tanaman kakao (Theobroma cacao L) telah dikenal di Indonesia sejak tahun 1560 , tetapi baru menjadi komoditi yang penting sejak tahun 1951. Perkembangan yang pesat dari penanaman kakao di Indonesia, menyebabkan peningkatan produksi secara cepat. Pada tahun 1970 1977 produksi kakao Indonesia hanya $2.000-3.000$ ton, tetapi pada tahun 1980 produksi kakao melonjak menjadi 7.000 ton (Siregar dkk, 2006). Pengembangan kakao di Indonesia sebagian besar dikelola dalam bentuk perkebunan rakyat. Tahun 2009, luas lahan kakao yang tercatat 92,6 persen dikelola oleh rakyat dan selebihnya 3,3 persen perkebunan besar negara serta 4,1 persen perkebunan besar swasta.

Peningkatan luas lahan dan jumlah petani kakao perkebunan rakyat di Provinsi Aceh tidak diikuti dengan peningkatan produksi dan produktivitas kakao. Untuk lebih jelasnya mengenai jumlah petani kakao di Provinsi Aceh selama 5 tahun diperlihatkan pada Tabel 1 .

\footnotetext{
${ }^{1}$ Mahasiswa Agribisnis Universitas Malikussaleh

${ }^{2}$ Staff Pengajar Program Studi Agribisnis Universitas Malikussaleh
} 
Tabel 1 : Luas Lahan, Produksi, Produktivitas dan Jumlah Petani Kakao Perkebunan Rakyat Di Provinsi Aceh, Tahun 2006 - 2010

\begin{tabular}{lllll}
\hline Tahun & $\begin{array}{l}\text { Luas Lahan } \\
\text { (Ha) }\end{array}$ & $\begin{array}{l}\text { Produksi } \\
\text { (Ton) }\end{array}$ & $\begin{array}{l}\text { Produktivitas } \\
\text { (Ton/Ha) }\end{array}$ & $\begin{array}{l}\text { Jumlah Petani } \\
\text { (KK) }\end{array}$ \\
\hline 2006 & 38.434 & 15.504 & 0,40 & 61.007 \\
\hline 2007 & 46.428 & 17.705 & 0,38 & 69.509 \\
\hline 2008 & 70.920 & 27.929 & 0,39 & 100.194 \\
\hline 2009 & 75.130 & 26.466 & 0,35 & 100.194 \\
\hline 2010 & 81.512 & 29.677 & 0.36 & 112.968 \\
\hline Jumlah & $\mathbf{3 1 2 . 3 3 3}$ & $\mathbf{1 1 7 . 1 2 6}$ & $\mathbf{0 , 3 7 5}$ & $\mathbf{4 4 3 . 8 7 2}$ \\
\hline Rata - rata & $\mathbf{6 2 . 4 6 6 , 6}$ & $\mathbf{2 3 . 4 2 5 , 2}$ & $\mathbf{0 , 3 7 5}$ & $\mathbf{8 8 . 7 7 4 , 4}$ \\
\hline
\end{tabular}

Sumber : Dinas Kehutanan Dan Perkebunan Aceh (diolah)

Dari tabel di atas dapat dilihat bahwa peningkatan luas lahan tanaman kakao perkebunan rakyat di Provinsi Aceh selama lima tahun di ikuti dengan peningkatan jumlah petani kakao perkebunan rakyat di Provinsi Aceh. Sedangkan produksi dan produktivitas kakao perkebunan rakyat setiap tahun mengalami fluktuasi.

Pada tahun 2009, produktivitas kakao di Provinsi Aceh sebesar0,35 ton/ha, jumlah produktivitas tersebut masih rendah dari produktivitas kakao di Sumatera Utara sebesar 0,58 ton/ha serta Sumatera Barat 0,45 ton/ha. Kakao yang dihasilkan oleh perkebunan rakyat di Provinsi Aceh baik dari segi produktivitas dan kualitas masih sangat rendah yang disebabkan oleh penggunaan bibit kakao unggul, kondisi kebun yang kurang terawat, umur tanaman yang sudah tua serta serangan hama dan penyakit (Burhanudin, 2012).

Usahatani kakao perkebunan rakyat di Provinsi Aceh masih bersifat tradisional. Pengelolaan tanaman kakao pada umumnya hanya mengandalkan tenaga kerja dalam keluarga. Selain itu, minimnya penerapan teknologi termasuk pemupukan dan teknologi lainnya. Hal ini juga terlihat di lapangan, secara umum perkebunan kakao rakyat kurang perawatan. Selain itu, data yang diperoleh dari Dinas Kehutanan dan
Perkebunan Provinsi Aceh menunjukkan bahwa dari tahun 2006 - 2010 luas lahan dan jumlah petani kakao perkebunan rakyat terus mengalami peningkatan, tetapi produksi dan produktivitas kakao perkebunan rakyat masih mengalami fluktuasi.

Penelitian ini bertujuan untuk mengetahui dan menganalisis pengaruh luas lahan dan tenaga kerja terhadap produksi kakao perkebunan rakyat di Provinsi Aceh.

\section{METODE PENELITIAN}

Penelitian ini dilakukan di wilayah Provinsi Aceh. Penentuan lokasi penelitian ini dilakukan secara sengaja (purpose sampling) yang didasarkan pada pertimbangan bahwa Aceh merupakan salah satu Provinsi yang menghasilkan produksi kakao dan mempunyai potensi wilayah yang cukup baik. Ruang lingkup penelitian adalah untuk menganalisis pengaruh luas lahan dan tenaga kerja terhadap produksi kakao perkebunan rakyat di Provinsi Aceh.

Data yang digunakan dalam penelitian ini adalah data sekunder yang bersumber dari instansi terkait. Dalam penelitian ini data sekunder yang digunakan jenis data cross section. Pengumpulan data yang dilakukan 
dalam penelitian ini dengan Metode dokumentasi. Metode ini dilakukan untuk mendapatkan data - data variabel input dan output yang sudah tersedia di Dinas Perkebunan dan Kehutanan Provinsi Aceh dan Biro Pusat Statistik

Aceh.

Data dalam penelitian ini diolah dengan menggunakan analisis regresi dalam bentuk logaritma (Widarjono, 2007). Selain itu statistik deskriptif digunakan untuk menggambarkan keadaan umum daerah penelitian. Model yang digunakan adalah fungsi produksi Cobb-Douglas. Secara umum dapat digambarkan sebagai berikut.

$\mathrm{Y}=\mathrm{b} 0 \mathrm{X} \mathbf{1}^{\mathrm{b} 1} \mathbf{X} \mathbf{2}^{\mathrm{b} 2}$

Untuk mempermudah perhitungan, dari fungsi (3.1) tersebut kemudian diubah dalam bentuk linear logaritma, sehingga persamaan matematisnya menjadi

$\operatorname{LnY}=\operatorname{Lnbo}+b 1 \operatorname{LnX} 1+b 2 \operatorname{LnX} 2+\varepsilon$

$$
\begin{array}{ll}
\mathrm{Y} & =\text { Produksi kakao }(\text { Ton }) \\
\mathrm{b} 0 & =\text { Intercep } \\
\mathrm{b} 1, \mathrm{~b} 2 & =\text { koefisien regresi } \\
\mathrm{X} 1 & =\text { Luas lahan kakao }(\mathrm{Ha}) \\
\mathrm{X} 2 & =\text { Tenaga kerja }(\mathrm{KK}) \\
\varepsilon & =\text { error term }
\end{array}
$$

Proses pengolahan data menggunakan paket program SPSS versi 16 , Sedangkan untuk mengetahui tingkat signifikansi variabel independen terhadap variabel dependen yang dianalisis dapat dilihat pada nilai $p$-value varibel tersebut baik secara individual $(\mathrm{t}$ test) maupun secara bersama-sama atau serentak (F-test).

\section{HASIL DAN PEMBAHASAN}

Analisis data dalam penelitian ini menggunakan analisis fungsi cobb douglas. Untuk melihat hasil estimasi model penelitian data yang diolah maka diperoleh hasil perhitungan analisis regresi seperti yang ditunjukkan pada Tabel 2 berikut ini:

\section{Keterangan:}

Tabel 2 : Pendugaan Parameter Model Regresi Cobb-Douglas Untuk Fungsi Produksi Kakao Di Provinsi Aceh

\begin{tabular}{|l|l|l|l|l|}
\hline $\begin{array}{l}\text { Variabel } \\
\text { Independen }\end{array}$ & $\begin{array}{l}\text { Koefisien } \\
\text { Regresi }(\boldsymbol{\beta})\end{array}$ & $\begin{array}{l}\text { Standard } \\
\text { Error }\end{array}$ & $\mathbf{t}$ & Sig \\
\hline Konstanta & -0.739 & 0.708 & -1.044 & 0.310 \\
\hline $\mathrm{LnX}_{1}$ & 1.153 & 0.194 & 5.953 & $0.000 *$ \\
\hline $\mathrm{LnX}_{2}$ & -0.097 & 0.217 & -.445 & 0.661 \\
\hline $\mathrm{R}=0,962$ & $\begin{array}{l}\text { a. Predictor (Constant): } \\
\mathrm{R}^{2}=0,925\end{array}$ & $\begin{array}{l}\text { Tenaga Kerja, Luas Lahan Kakao } \\
\mathrm{F}_{\text {hitung }}=117,149 \\
\mathrm{Sig} \mathrm{F}=0,000\end{array}$ & $\begin{array}{l}\text { Dependen Variabel : } \\
\text { Produksi Kakao }\end{array}$ & \\
& &
\end{tabular}

Sumber: Data Sekunder, 2011 (diolah)

Keterangan : *) signifikan pada taraf signifikansi 0.01

Berdasarkan hasil analisis regresi fungsi produksi Cobb - Douglas dalam Tabel 2 maka dapat disusun kedalam persamaan linear logaritma berikut ini.

$$
\begin{aligned}
& \operatorname{LnY}=\operatorname{Lnbo}+b_{1} \operatorname{Ln} X_{1}-b_{2} \operatorname{LnX}_{2}+\varepsilon \\
& \operatorname{LnY}=(-0,739)+1,153 \operatorname{LnX}_{1}- \\
& 0,097 \operatorname{Ln} X_{2}+\varepsilon
\end{aligned}
$$


Dari persamaan regresi dapat diketahui hasil penelitian sebagai berikut:

Koefisien korelasi ganda sebesar $0,962(\mathrm{R}=96,2 \%)$, artinya tingkat keeratan hubungan antara variabel luas lahan dan tenaga kerja terhadap produksi kakao sangat kuat karena nilai korelasi ganda berada di antara 0,80 - 1,00. Variasi pengaruh variabel luas lahan $\left(\mathrm{X}_{1}\right)$ dan tenaga kerja $\left(\mathrm{X}_{2}\right)$ terhadap variabel produksi kakao (Y) ditunjukkan oleh koefisien determinasi $\left(\mathrm{R}^{2}\right)$. Besarnya $\mathrm{R}^{2}$ adalah 0,925 , yang artinya variasi variabel luas lahan $\left(\mathrm{X}_{1}\right)$ dan tenaga kerja $\left(\mathrm{X}_{2}\right)$ mampu menjelaskan 92,5\% variasi variabel produksi kakao, sedangkan sisanya 7,5\% dijelaskan oleh variabel lain yang tidak dimasukkan dalam model penelitian ini.

Hasil estimasi Uji $\mathrm{F}$ menunjukkan bahwa nilai $F_{\text {hitung }}$ sebesar $117.149>\mathrm{F}_{\text {tabel }} 3.522$ atau nilai $\mathrm{F}_{\text {sig }}=$ $0,000<\alpha=0,01$. Hal ini dapat disimpulkan bahwa uji hipotesis statistik pada penelitian ini dapat diterima yang berarti variabel luas lahan $\left(\mathrm{X}_{1}\right)$ dan tenaga kerja $\left(\mathrm{X}_{2}\right)$ yang digunakan dalam model secara serempak berpengaruh signifikan terhadap produksi kakao (Y) perkebunan rakyat di Provinsi Aceh.

Pengujian secara parsial (Uji t) dari masing - masing variabel luas lahan $\left(\mathrm{X}_{1}\right)$ dan tenaga kerja $\left(\mathrm{X}_{2}\right)$ terhadap produksi kakao $(\mathrm{Y})$ perkebunan rakyat di Provinsi Aceh sebagai berikut :

\section{Pengaruh Luas Lahan Terhadap Produksi Kakao}

Nilai Koefisien regresi variabel luas lahan $\left(\mathrm{X}_{1}\right)$ sebesar 1,153 menunjukkan bahwa variabel luas lahan meningkat sebesar 1 persen maka akan meningkatkan produksi kakao perkebunan rakyat sebesar 1,153 persen dengan asumsi bahwa variabel lainnya dianggap konstan. Dari nilai koefisien sebesar 1,153 luas lahan $\left(\mathrm{X}_{1}\right)$ memperlihatkan tingkat elastisitas terhadap produksi kakao bersifat elastis.

Variabel luas lahan $\left(\mathrm{X}_{1}\right)$ memiliki nilai probabilitas signifikan $0,000<\alpha=0,01$ berarti bahwa variabel luas lahan $\left(\mathrm{X}_{1}\right)$ berpengaruh signifikan secara parsial terhadap produksi kakao (Y) perkebunan rakyat di Provinsi Aceh. Hasil arah hubungan antara variabel luas lahan $\left(\mathrm{X}_{1}\right)$ dengan produksi kakao $(\mathrm{Y})$ perkebunan rakyat di Provinsi Aceh memiliki hubungan yang positif. Hal ini sesuai dengan teori yaitu lahan sebagai salah satu faktor produksi yang merupakan pabriknya hasil pertanian yang mempunyai kontribusi yang cukup besar terhadap usaha tani. Besar kecilnya produksi dari usaha tani antara lain dipengaruhi oleh luas sempitnya lahan yang digunakan (Mubyarto, 1994). Kesimpulan ini didukung oleh hasil penelitian Firmandewi (2007) yang menyatakan bahwa variabel luas lahan berpengaruh nyata terhadap produksi cengkeh di Provinsi Bali.

\section{Pengaruh Tenaga Kerja Terhadap Produksi Kakao}

Variabel tenaga kerja $\left(\mathrm{X}_{2}\right)$ memiliki nilai probabilitas signifikan $0,661>\alpha=0,05$ berarti bahwa variabel Tenaga kerja $\left(\mathrm{X}_{2}\right)$ tidak berpengaruh signifikan secara parsial terhadap produksi kakao (Y) perkebunan rakyat di Provinsi Aceh. Hasil ini menjelaskan bahwa peningkatan jumlah tenaga kerja yang digunakan dalam usaha tani kakao belum tentu dapat meningkatkan produksi kakao yang berarti. Tidak adanya pengaruh signifikan ini disebabkan oleh penggunaan tenaga kerja yang belum efisien, dan masih minimnya pengetahuan serta ketrampilan dalam mengelola perkebunan secara tepat dan terpadu 
sehingga dapat berpengaruh terhadap kuantitas dan kualitas produksi kakao perkebunan rakyat di Provinsi Aceh.

Arah hubungan antara variabel tenaga kerja dengan produksi kakao perkebunan rakyat di Provinsi Aceh memiliki hubungan yang negatif. Kesimpulan dari penelitian ini didukung oleh penelitian dari Sudaryati (2004) yang menyatakan bahwa variabel tenaga kerja berpengaruh tidak nyata terhadap produksi kopi rakyat di Kabupaten Temanggung.

Berdasarkan hasil estimasi tingkat produksi kakao perkebunan rakyat di Provinsi Aceh diperoleh hasil bahwa fungsi produksi berada pada kondisi increasing return to scale. Jika dijumlahkan koefisien $\mathrm{X}_{1}+\mathrm{X}_{2}$ lebih besar dari satu maka nilai elastisitas produksi $1,153+(-0,097)=1,056$. increasing return to scale yang berarti bahwa persentase pertambahan kuantitas produksi lebih besar dengan pertambahan kuantitas faktor produksi luas lahan dan tenaga kerja. Setiap penambahan $1 \%$ akan menyebabkan kenaikan output yang lebih besar dari 1 $\%$. Oleh karena itu, pada daerah increasing return to scale produksi kakao perkebunan rakyat di Provinsi Aceh akan selalu bisa ditingkatkan dengan cara menambahkan input.

\section{KESIMPULAN}

Berdasarkan dari hasil penelitian dapat disimpulkan sebagai berikut:

1. Hasil penelitian menunjukkan bahwa secara serempak luas lahan $\left(\mathrm{X}_{1}\right)$ dan tenaga kerja $\left(\mathrm{X}_{2}\right)$ berpengaruh signifikan terhadap produksi kakao (Y). Sedangkan secara parsial luas lahan $\left(\mathrm{X}_{1}\right)$ tanaman kakao di Provinsi Aceh memiliki pengaruh signifikan terhadap produksi kakao (Y) pada taraf signifikasi 0,01 . Sedangkan tenaga kerja $\left(\mathrm{X}_{2}\right)$ tidak berpengaruh signifikan terhadap produksi kakao di Provinsi Aceh pada taraf signifikasi 0,05 .

2. Usahatani kakao di Provinsi Aceh berada pada kondisi increasing return to scale atau berada pada kondisi produksi yang semakin meningkat. Penambahan faktor produksi dalam usahatani kakao akan menghasilkan pertambahan produksi yang lebih besar.

\section{SARAN}

1. Kepada petani diharapkan agar dapat menambah jumlah luas lahan untuk mendorong peningkatan produksi kakao di Provinsi Aceh dan diharapkan juga penggunaan tenaga kerja lebih efisien dalam proses kegiatan usahatani perkebunan kakao rakyat.

2. Diharapkan kepada pemerintah di Provinsi Aceh khususnya dinas Perkebunan untuk lebih aktif dalam memberikan bimbingan/penyuluhan kepada petani kakao tentang efisiensi penggunaan input produksi sehingga dapat meningkatkan produksi dan produktivitas kakao perkebunan rakyat di Provinsi Aceh.

3. Diharapkan kepada peneliti selanjutnya untuk dapat mengidentifikasi variabel variabel lainnya yang mempengaruhi produksi kakao seperti modal, teknologi, dan lainnya. 


\section{DAFTAR PUSTAKA}

Burhanudin Mohammad. 2012. Produksi Kakao Aceh Terendah Di Sumatera. Surat Kabar Kompas. $\quad$ http://bisnis keuangan. kompas. com/ read/ 2012/02/23/17555148/

Produksi. Kakao. Aceh. Terendah. Di Sumatera. (20 Juli 2012).

Firmandewi Nonik. 2007. Analisis Pengaruh Luas Areal Dan Jumlah Tenaga kerja Terhadap Produksi Cengkeh Di Provinsi Bali. Fakultas Ekonomi Universitas Udayana. Denpasar. http://\%3A\%2F\%2Fwww. pps.unud.ac.id\%2F thesis\%2Fpdf thesis\% 2Funud-149-705113797. pdf. (13 Sept 2012).
Mubyarto. 1994. Pengantar Ekonomi Pertanian. LP3ES. Yogyakarta.

Siregar H.S. Tumpal, dkk. 2006. Budidaya, Pengolahan Dan Pemasaran Cokelat. Penebar Swadaya. Jakarta.

Sudaryati Endang. 2004. Faktor - Faktor Yang Mempengaruhi Produksi Kopi Di Kabupaten Temanggung (Studi Kasus Di Kecamatan Candiroto Kabupaten Tenanggung). Fakultas Ilmu Ekonomi Dan Studi Pembangunan. Universitas Diponegoro. Semarang.

Widarjono Agus. 2007. Ekonometrika: Teori dan Aplikasi untuk Ekonomi dan Bisnis. Edisi kedua. Ekonisia. Yogyakarta 